\title{
IMPLEMENTING THE COUNTERCYCLICAL CAPITAL BUFFER in South Africa: Practical Considerations
}

\author{
Pravin Burra \\ Deloitte and Touche
}

Pieter Juriaan de Jongh

Centre for Business Mathematics and Informatics (BMI), North-West University

Helgard Raubenheimer

Centre for BMI, North-West University

Gary van Vuuren

North-West University

\section{Henco Wiid}

Centre for BMI, North-West University and Deloitte and Touche

Accepted: July 2014

The Basel II regulatory framework significantly increased the resilience of the banking system, but proved ineffective in preventing the 2008/9 financial crisis. The subsequent introduction of Basel III aimed, inter alia, to supplement bank capital using buffers. The countercyclical buffer boosts existing minimum capital requirements when systemic risk surges are detected. Bolstering capital in favourable economic conditions cushions losses in unfavourable conditions, thereby addressing capital requirement procyclicality. This paper contains an overview of the countercyclical capital buffer and a critical discussion of its implementation as proposed in Basel III. Consequences of the buffer's introduction for South African banks are explored, and in particular, potential systemic risk indicator variables are identified that may be used by the South African Reserve Bank (SARB) as early warning indicators of imminent systemic financial distress. These indicators may be of value to the SARB, which could use them in taking decisions on the build-up and release of the countercyclical buffer for South African banks.

Key words: Basel III, procyclical, countercyclical, buffer capital

JEL: C134, 16, 53

\section{1}

\section{Introduction}

The financial crisis of 2008-9 resulted in substantial losses in the banking sector and highlighted the risk of procyclicality within the financial sector. According to Athanasoglou, Daniilidis and Delis (2014), procyclicality has transformed banks from mitigation mechanisms to amplifiers of changes in economic activity potentially affecting financial stability and economic growth. They state that the causes of procyclicality can be attributed to market imperfections and deviations from the efficient market hypothesis, Basel-type regulations, and accounting standards. In their review paper they review the causes and consequences of the intense procyclicality in the banking sector and its relationship with the real economy, and discuss the potential regulatory intervention which aims to smooth the cyclical variation of bank credit.

Against this background this paper focuses on mitigating mechanisms for procyclicality 
such as the countercyclical capital buffer proposed in Basel III and some of the associated implementation issues. The latter will be explored from a South African perspective.

It is well known that the recent financial crisis was preceded by a period of excess credit growth which destabilised the banking sector, and in turn exacerbated a downturn in the real economy, which led to further destabilisation of the banking sector. These interdependencies demonstrated the importance of capital defence accumulation in the banking sector while credit extension is growing to excessive levels. To this end, Basel III introduced the new capital conservation buffer and the countercyclical capital buffer. The idea behind the capital conservation buffer is that it should serve as an extra cushion on top of minimum capital requirements to make banks more resilient in the current volatile global financial sector. When a bank's capital adequacy ratio decreases to a point where it enters the range of the capital conservation buffer, the national regulator should impose restrictions on earnings distribution until the buffer has been rebuilt to its required level. The countercyclical capital buffer, which is the focus of this article, should serve as a further extension of up to 2.5 per cent of risk-weighted assets (RWA) to the capital conservation buffer. In the event of a build-up of systemic risk due to excess aggregate credit growth, the regulator should enforce this buffer. The countercyclical capital buffer functions on the same principles as the capital conservation buffer, with the main objective of building up an extra buffer in good times that can serve as a cushion and be drawn down to absorb losses in bad times. In that way it helps to address the pro-cyclicality of capital requirements. A key element of the Basel III proposal was the identification of a set of variables, within a jurisdiction, to assess whether there was significant risk that credit had grown to excessive levels (BCBS, 2009). The proposal asserted that the countercyclical capital buffer (CCB) should be deployed when these variables breached pre-defined thresholds, at which point benchmark buffer requirements would be activated. One such variable, proposed by the BCBS, is the credit-to-GDP gap, which is the difference between the aggregate credit-to-GDP ratio and its longterm trend. The implementation of such a strict rules-based regime inevitably requires an unattainable degree of confidence that the ratio would perform as intended under all circumstances and not deliver false signals. Nevertheless, a later consultative document reinforced the Basel Committee on Banking Supervision's resolve to employ this ratio (BCBS, 2010a). Subsequently, the Basel III document and guidance for national authorities operating the $\mathrm{CCB}$ were published simultaneously (BCBS, 2010a).

The countercyclical capital buffer constitutes the most significant macro-prudential element of the Basel III package and this article provides a broad overview of the $\mathrm{CCB}$ and the global developments pertaining to the $\mathrm{CCB}$ as well as an assessment of how the CCB proposals may be implemented in South Africa. This will include a critical discussion of the credit-to-GDP gap as an early warning indicator for eminent financial distress periods as well as an examination of relevant literature in this regard. The main contribution of the paper is the identification of conditioning variables that could serve as leading indicators of a build-up of systemic risk due to excess aggregate credit growth specific to South Africa.

The article is organised as follows: Section 2 covers a brief overview of the origin, definition and implementation of the CCB. Section 3 provides a description of where the CCB fits into the Basel III framework and discusses the guidelines given by Basel III on implementation of the CCB by national regulators. Section 4 contains a critical discussion of the global implementation of the CCB and makes recommendations on its implementation from a South African perspective. In particular, the credit-to-GDP gap is analysed, and criticised, as a leading indicator of financial distress from a global and local perspective. A number of economic variables are analysed in order to find a set of indicators that could help the South African Reserve Bank (SARB) in making decisions regarding the build-up and release of the CCB. In Section 5, the main findings are summarised and some recommendations are made for future research. 
2

\section{The conservation and countercyclical capital buffers}

Basel III specified the minimum total capital requirements of banks as $8 \% \times R W A$ (riskweighted assets) of which at least $4.5 \% \times R W A$ should be Common Equity Tier 1 (CET1) capital and $6 \% \times R W A$ should be Tier 1 capital. Basel III introduced the capital conservation and countercyclical capital buffers to ensure that banks accumulate capital buffers above the regulatory minimum in profitable times and then draw down on these in periods of stress. Banks are required to hold a capital conservation buffer of $2.5 \% \times R W A$ above the regulatory minimum capital requirement, consisting solely of CET1 capital. If a bank breaches this buffer, constraints are applied to the distribution of earnings to ensure that banks build up this buffer again before redistributing profits. Banks are able to conduct business as normal when the buffer is breached as no constraints are mandated on the bank's operations, but only on the distribution of funds. Note that this does not stop the regulator from applying such other constraints as may be deemed to be appropriate under the particular circumstances. Furthermore, a countercyclical capital buffer (CCB) of up to $2.5 \% \times R W A$, again consisting solely of CET1 capital, may be deployed when national authorities detect a build-up of system-wide risk associated with excess aggregate credit growth to ensure that the banks have sufficient capital buffers to cover the potential future losses when the economic cycle turns. It should be noted that the aim of the CCB is not only to increase the amount of capital held by banks, but also to make sure that it is of high quality in the form of CET1 capital to ensure proper absorption of losses. The buffer is to be deployed on an infrequent basis (perhaps only once every 10 to 20 years), as the focus is on aggregate credit growth. Internationally active banks would, however, be required to carry smaller buffers on a more frequent basis as business cycles between different jurisdictions in which they have credit exposures would not always be highly correlated (BCBS, 2010b).

Table 1 shows the minimum capital conservation ratios banks would be required to meet at the respective levels of CET1 capital ratios. For example, a bank with a CET1 capital ratio of between 6.375 per cent and 5.750 per cent would be required to conserve 60 per cent of its earnings in the subsequent financial year (i.e. payout no more than 40 per cent in terms of share buybacks, dividends and discretionary bonus payments). If a bank is operating at a CET1 ratio below 5.125 per cent, no dividend distribution would be allowed, while if a bank is operating at a CET1 ratio above 7 per cent there would be no constraints on dividend distribution.

Using a specific example and the Basel II advanced internal ratings-based approach, the BCBS (2011) demonstrated how the capital conservation buffer enhances the resilience of the banking system. The total minimum capital requirement of $(8$ per cent +2.5 per cent $=)$ 10.5 per cent implies a confidence level of 99.97 per cent instead of the 99.90 per cent employed by the previous total minimum requirement of 8 per cent. This is shown in Figure 1 below.

Table 1

Individual bank minimum capital conservation standards

\begin{tabular}{|c|c|}
\hline $\begin{array}{c}\text { Common equity } \\
\text { Tier 1 ratio }\end{array}$ & $\begin{array}{c}\text { Minimum capital conservation ratios } \\
\text { (expressed as \% of earnings) }\end{array}$ \\
\hline $4.500 \%-5.125 \%$ & $100 \%$ \\
\hline $5.125 \%-5.750 \%$ & $80 \%$ \\
\hline$>5.750 \%-6.375 \%$ & $60 \%$ \\
\hline$>6.375 \%-7.000 \%$ & $40 \%$ \\
\hline$>7.000 \%$ & $0 \%$ \\
\hline
\end{tabular}

Source: BCBS of Banking Supervision (BCBS, 2011) 


\section{Figure 1}

The increase in the resiliency of the banking sector due to the capital conservation buffer

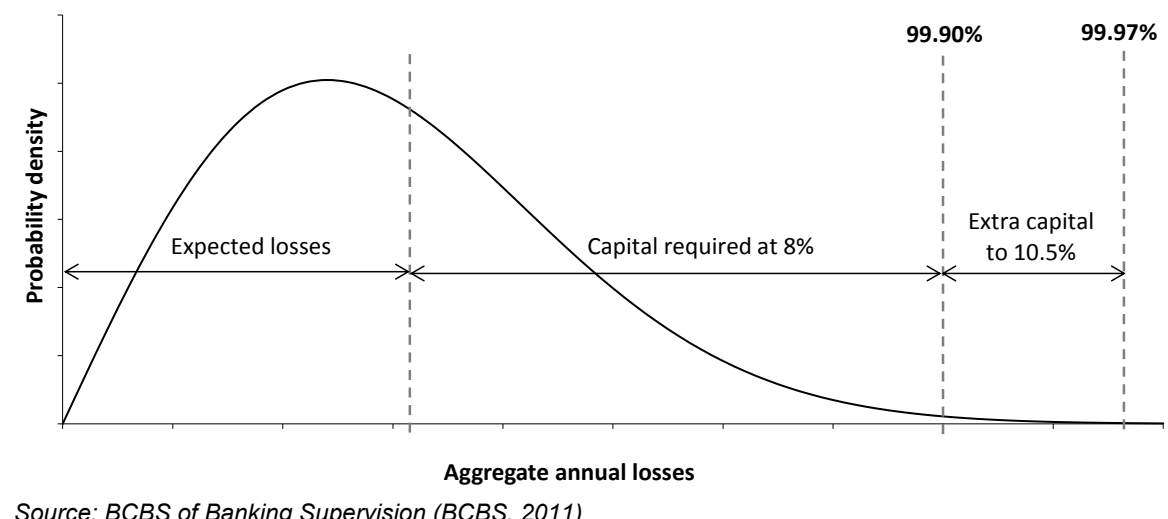

Source: BCBS of Banking Supervision (BCBS, 2011)

The CCB to which a bank would be subjected is implemented through an extension of the capital conservation buffer. It must be met entirely from CET1 capital or other fully lossabsorbing capital. Table 2 sets out the conservation ratios a bank must meet at various levels of CET1 capital if the bank is subject to a $2.5 \% \times R W A$ CCB requirement.

A detailed schedule reflecting how the new capital requirements should be phased-in is proposed in BCBS (2011). The countercyclical buffer regime will be phased-in in parallel with the capital conservation buffer between 1 January 2016 and year-end 2018, becoming fully effective on 1 January 2019. The maximum countercyclical buffer requirement, like the conservation buffer, will therefore begin at 0.625 per cent of RWAs on 1 January 2016 and increase each subsequent year by an additional 0.625 per cent, to reach its final maximum of 2.500 per cent of RWAs on 1 January 2019. In addition, jurisdictions may choose to implement higher countercyclical buffer requirements. In such cases, the reciprocity provisions of the regime would not apply to the additional amounts or earlier time frames.

Table 2

Individual bank minimum capital conservation standards, when a bank is subject to a $2.5 \% \times R W A$ countercyclical requirement

\begin{tabular}{|c|c|}
\hline $\begin{array}{c}\text { Common equity } \\
\text { Tier 1 ratio }\end{array}$ & $\begin{array}{c}\text { Minimum capital conservation ratio } \\
\text { (expressed as \% of earnings) }\end{array}$ \\
\hline $4.50 \%-5.75 \%$ & $100 \%$ \\
\hline$>5.75 \%-7.00 \%$ & $80 \%$ \\
\hline$>7.00 \%-8.25 \%$ & $60 \%$ \\
\hline$>8.25 \%-9.50 \%$ & $40 \%$ \\
\hline$>9.50 \%$ & $0 \%$ \\
\hline
\end{tabular}

Source: BCBS of Banking Supervision (BCBS, 2011)

Prior, during and after the work of the Basel Committee for Banking Supervision as detailed in Basel III, a number of authors discussed ways of incorporating the business cycle into the provisioning of capital charges. Kashyap and Stein (2004) proposed a simple framework for optimal bank capital regulation according to which the state of the business cycle determined capital charges. Repullo and Saurez (2009) followed a positive approach, in contrast with the normative approach of Kashyap and Stein (2004). Under risk-based 
capital requirements, banks were found to hold larger buffers in expansionary economic periods than in recessionary ones, but these were insufficient to prevent substantial credit supply contractions when recessions arose (Repullo \& Saurez, 2009). Time-varying capital requirements were also advocated by Hanson et al. (2011) and Shleifer and Vishny (2010). Repullo, Saurina and Trucharte (2010) used Spanish data to compare different methodologies in order to adjust the minimum capital requirements over different phases of the business cycle. The conclusion was that the best procedure would be to smooth the output and use a multiplier based on GDP growth (Repullo et al., 2010; Drehmann, Cláudio, Gambacorta, Jimenez \& Trucharte, 2010). This is discussed in more detail in Section 4.

It should be noted that the SARB has introduced a number of capital add-on requirements for South African banks, but is obliged to follow the Basel III guidelines in introducing the conservative and countercyclical buffers (see SARB, 2011) in addition to the add-ons. According to the Basel III framework, the minimum Tier 1 capital ratio that a bank must maintain, when a maximum CCB of $2.50 \% \times R W A$ is deployed, is 10.5 per cent and accordingly the minimum capital adequacy ratio is 13.0 per cent. Table 3 below shows the capital adequacy ratio and the Tier 1 capital to risk-weighted assets for the top four banks in South Africa. It is clear that South African banks are well capitalised and operate in excess of the Basel minimum requirements, even if a maximum $\mathrm{CCB}$ of $2.50 \% \times R W A$ is deployed.

Nonetheless, the SARB (SARB, 2011) has indicated that the $\mathrm{CCB}$ will be used to further increase the resiliency of the banking sector in South Africa. The planned implementation date for the instrument is 1 January 2016.

Table 3

Capital-adequacy ratio and Regulatory Tier 1 capital to risk-weighted assets of the top four banks in South Africa for the first semester of 2012

\begin{tabular}{|l|c|c|c|c|c|c|}
\hline \multicolumn{1}{|c|}{2012} & Jan & Feb & Mar & Apr & May & Jun \\
\hline Capital adequacy ratio & 14.75 & 14.66 & 14.70 & 14.71 & 14.68 & 14.80 \\
\hline Regulatory Tier 1 capital to risk-weighted assets & 11.84 & 11.73 & 11.69 & 11.70 & 11.73 & 11.84 \\
\hline
\end{tabular}

3

\section{Guidelines for countercyclical capital buffer decisions}

BCBS (2010a) provides guidance to national authorities (SARB in South Africa) on operating the countercyclical capital buffer and sets out the responsibility of the national authority in making buffer decisions. It also requires the national authority to use a credit/GDP reference guide to gauge the build-up of system-wide risk in order to set up the countercyclical buffer. It is important to note that the BCBS does not restrict the national authority to the credit/GDP reference guide and encourages national authorities to evaluate other leading indicators that would help assess a build-up of system-wide risk through excess aggregate credit growth. Furthermore, BCBS (2010a) provides principles when arriving at decisions on the setting of the buffer and discusses the jurisdiction reciprocity when it comes to large internationally active banks. This section contains a brief overview and discussion of BCBS (2010a) with respect to the guidelines given regarding national buffer decisions, the reference guide and principles to be used in decisions regarding the countercyclical buffer, and further details on operating the CCB.

\subsection{National buffer decisions}

In its guidelines (BCBS, 2010a) the BCBS states that it is the responsibility of the national authority to monitor credit growth and make assessments on whether there is excess aggregate credit growth that is associated with a build-up of system-wide risk. Given this assessment by the national authority, it should use its discretion on whether to deploy the CCB or not. Whether the buffer should increase, decrease or stay unchanged over time is another judgment call. The national authority 
should also be prepared to remove the buffer when appropriate. Conceptually this should coincide with the period of distress following the build-up of any credit bubble.

Furthermore, the national authority should pre-announce any increase of the buffer up to 12 months in advance. This ensures that banks have enough time to meet the new (higher) capital requirements before they take effect (BCBS, 2011). The release of the buffer amount should coincide with the period of stress following the build-up of a credit bubble. This helps alleviate some of the credit constraint pressure that would otherwise arise. Exactly how this is to be achieved in practice is a frequently debated question; currently it is left to the discretion of the regulator. The effects of not meeting the CCB would be the same as for the capital conservation buffer and would ensure that banks build up enough capital before distributing earnings to shareholders.

\subsection{Common reference guide and principles for promoting sound decisions}

BCBS (2010a) expects national authorities to apply their own judgment when making buffer decisions and to make use of the best information available. This approach, in which discretion is guided by information, is designed to ensure a degree of consistency over time in the decisions taken, while providing the necessary flexibility, given the inherent uncertainty and the lack of experience associated with operating a CCB. In addition, national authorities are expected to calculate the internationally consistent buffer that can serve as a common starting reference point for taking buffer decisions.

The common reference guide that can be used to gauge the build-up of system-wide risk is based on the aggregate private sector creditto-GDP gap and the methodology for calculating this is presented in BCBS (2010a), in which it is acknowledged that the credit/ GDP reference guide is not always expected to work well in all jurisdictions and at all times, and that national authorities should explore other indicators to guide them in making buffer decisions. To this end, the BCBS formulated the following principles to guide authorities on how to use their own judgment within this framework. Some remarks will be made after stating each principle.

Principle 1: Buffer decisions should be guided by the objectives to be achieved by the buffer, namely to protect the banking system against potential future losses when excess credit growth is associated with an increase in system-wide risk.

It is clear that the CCB may not be used as an instrument to manage economic cycles and asset prices. Where necessary, these issues can best be addressed through monetary, fiscal and other public policy actions. It is very important that buffer decisions should only be taken after taking into consideration all of the supervisory, financial and prevailing economic information available, bearing in mind that the decision may have an influence on monetary and fiscal policies.

Principle 2: The credit/GDP guide is a useful common reference point in taking buffer decisions. It does not need to play a dominant role in the information used by authorities to take and explain buffer decisions. Authorities should explain the information used, and how it is taken into account in formulating buffer decisions.

The national authority is free to and should evaluate other leading indicators that would help assess a build-up of system-wide risk through excess aggregate credit growth. These indicators should assist in confirming or rejecting the signals given by the credit-toGDP guide. It must be stressed, however, that almost any indicator will sometimes give misleading signals. It is therefore crucial to use both judgment and a set of indicators when making any decisions.

Principle 3: Assessments of the information contained in the credit/GDP guide and any other guides should be mindful of the behaviour of the factors that can lead them to give misleading signals.

The national authority can release the buffer gradually when credit growth slows and there is a reduction in system-wide risk. In other situations the buffer can be released promptly to reduce the risk of the credit supply chain 
being constrained by regulatory capital requirements. The national authority may pace the release of the buffer in tandem with the release of loss information from the banking sector to ensure that banks have capital released to cover their losses or absorb an increase in risk-weighted assets.

Principle 4: Promptly releasing the buffer in times of stress can help to reduce the risk of the supply of credit being constrained by regulatory capital requirements.

If the national authority decides to release the buffer promptly it is recommended that the national authority indicate exactly how long they expect the release to last. This will help to reduce uncertainty about future bank capital requirements and give banks the assurance that the capital released can be used to absorb losses and avoid constraining asset growth.

Principle 5: The buffer is an important instrument in a suite of macroprudential tools at the disposal of the authorities.

National authorities should deploy the buffer, preferably in tandem with other macroprudential tools, when excess aggregate credit growth is judged to be associated with a buildup of system-wide risk. This would ensure that banks have an additional buffer of high quality capital available to protect the banking sector from future losses. Alternative tools such as sectorial capital buffers may be used where there is excess credit growth in specific sectors that are not judged to be accompanied by system-wide risk.

\subsection{Further guidelines for operating the countercyclical buffer regime}

BCBS (2010a) also provides guidance on how buffer decisions should be communicated, the frequency of buffer estimations and decisions, interaction between Pillar I and II capital, treatment of the surplus when the $\mathrm{CCB}$ is released fully, and various other considerations for national authorities which are not within the scope of this paper. However, some remarks regarding the first two are made below.

Communicating buffer decisions is key to promoting accountability and sound decisionmaking. The CCB is a new addition to minimum capital requirements and it would be reasonable to give national authorities some time to gain experience in operating the buffer and developing an effective communication strategy specific to the buffer before explaining the decisions underpinning the buffer add-on. BCBS (2011a) proposed that the buffer framework should be implemented through a combination of minimum standards and best practice guidance. The minimum standards would describe: (a) the mechanics of the buffer approach, i.e. the information the banks need to comply with the rules; and (b) the information that all authorities are expected to disclose, i.e. any changes to the CCB in effect in their jurisdiction, and, on a regular and timely basis, the credit/GDP data used to calculate the common reference guide. BCBS (2010a) requires all announced changes to the prevailing buffer requirement to be reported to the BIS on a timely basis.

As far as the frequency of estimations and decisions is concerned, national authorities should ensure that there is consistency with the minimum capital requirements, and therefore the buffer add-on of individual banks must be calculated at least as frequently as their minimum capital requirements. The buffer should be calculated according to the latest buffer set by the national authority on the date on which their minimum capital requirements are calculated. Most of the information that would be used to make decisions regarding the CCB should be released on a monthly or quarterly basis by the national authority. It is therefore recommended that the national authority make announcements on the level of the CCB every quarter, even if the buffer stays unchanged at zero. This frequent revision would ensure that signals would be detected early enough to ensure that after the announcement of the deployment of the CCB, banks would have enough time to build the buffer before the credit cycle turns. Regular updates from the national authority on their assessment of the macrofinancial situation and their predictions for the near future would help banks and other stakeholders to prepare for potential buffer add-ons and give them time to adjust their capital planning accordingly. 
4

\section{Build-up and release indicators: options for South Africa}

This section is concerned with finding suitable indicators that can be used by regulators to assist them in the decisions that need to be taken regarding the build-up and release of the CCB. According to BCBS (BCBS, 2010a), an effective system is characterised, among others, by

- correctly timing the accumulation and release of the capital buffer, and

- ensuring that the $\mathrm{CCB}$ is built up in favourable economic conditions and is sufficiently large to absorb losses without triggering serious stress on the banking sector.

The next subsection provides an overview of the Basel guidelines regarding the build-up and release of the CCB together with a review of the literature that discusses the practicality of those guidelines. The following subsections will then concentrate on finding suitable buildup and release indicators in a South African context.

\subsection{A review of the Basel guidelines on managing the $C C B$ using the credit-to-GDP gap}

The BCBS (2010c) suggests that regulators should consider the credit-to-GDP gap as a possible means of managing the $\mathrm{CCB}$, because historical data show that if credit grows at a faster rate than the economy, the chances of a financial crisis increase significantly. The
credit-to-GDP gap $z_{t}$ is defined as the deviation of the credit-to-GDP ratio $x_{t}$ from its long-term trend $\bar{x}_{t}$, i.e. $z_{t}=x_{t}-\bar{x}_{t}$. The long-term trend $\bar{x}_{t}$ is computed as the Hodrick-Prescott trend of $x_{t}$, using a smoothing parameter $\lambda=400000$ (see e.g. Van Vuuren, 2012). The incorporation of the long-term trend ensures that possible changes in the long-term level of the ratio, which can be caused by financial deepening, are taken into account. The creditto-GDP ratio is a normalisation of credit growth relative to economic growth. This ratio would be large if the gap between credit growth and GDP growth widens, which typically happens when credit growth increases and GDP growth decreases, hence this factor is a good indication of whether credit growth is associated with an economic boom and is "healthy", or is not associated with economic growth and is "potentially toxic".

The benchmark countercyclical capital buffer, $b_{t}$, is set according to:

$$
\begin{aligned}
b_{t} & =b\left(z_{t}\right)=0 \% \times R W A \quad \text { if } z_{t}<L \\
& =\left(\frac{z_{t}-L}{H-L}\right) \cdot 2.5 \% \times R W A \text { if } L \leq z_{t} \leq H \\
& =2.5 \% \times R W A \quad \text { if } H<z_{t}
\end{aligned}
$$

where $L=0 \% \times R W A$ and $H=2.5 \% \times R W A$ denote lower and upper thresholds for the gap. The buffer is 0 when the gap is less than the lower threshold and is at its maximum level $2.5 \% \times R W A$ when the gap is greater than the upper threshold. Between these two levels, the buffer is a linearly increasing function of the gap. Figure 2 plots the relationship between the CCB and the credit-to-GDP gap.

Figure 2

Relationship between the countercyclical capital buffer and the credit-to-GDP gap

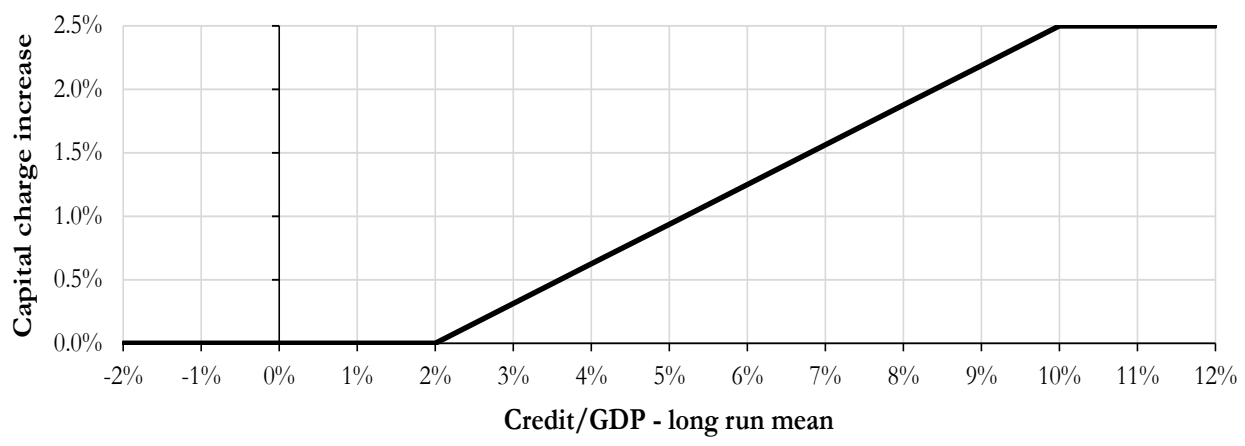


The rationale for this specification of the buffer in BCBS (2010b) as well as for the choice of the credit-to-GDP gap as the "common reference point" for taking buffer decisions is found in Drehmann et al. (2010). Their analysis shows that the best variables which could be used as signals for the pace and size of the accumulation of the buffers are not necessarily the best at signalling the timing and intensity of the release. Credit seems to be preferable for the build-up phase. In particular, when measured by the deviation of the creditto-GDP ratio from its trend, it has demonstrated leading indicator properties for financial distress. Drehmann, et al. (2010) conclude that some measure of aggregate banking sector losses, possibly combined with indicators of credit conditions, seems best for signalling the beginning of the release phase.

Beck and Demirguc-Kunt (2009) criticise the use of the credit-to-GDP gap as a leading indicator of financial distress. Using GDP growth and credit-to-GDP gap data for a number of countries over the period 19862009, Beck and Demirguc-Kunt (2009) show that the credit-to-GDP gap is negatively correlated with GDP growth in all selected countries except Germany, where there is a weak positive correlation. The results are reproduced in Table 4.

\section{Table 4}

Correlation of the credit-to-GDP gap with GDP growth around the globe

\begin{tabular}{|l|c|c|c|c|c|c|c|c|}
\hline \multicolumn{1}{|c|}{ Country } & France & Germany & Italy & Japan & Spain & UK & US & South Africa \\
\hline $\begin{array}{l}\text { Correlation with real } \\
\text { GDP growth }\end{array}$ & -0.61 & 0.07 & -0.32 & -0.26 & -0.43 & -0.72 & -0.23 & -0.27 \\
\hline
\end{tabular}

Source: Beck and Demirguc-Kunt (2009)

The conclusion from these results is that the variable chosen by the BCBS as a "common reference point" for taking buffer decisions fails to live up to the Hippocratic dictum: First, do no harm (Gordy, 2009). Its correlation with GDP growth is mostly negative, which means that the credit-to-GDP gap tends to signal a need to reduce capital requirements when GDP growth is high, and to increase capital requirements when GDP growth is low. This implementation of the CCB contradicts the mandate of the G-20, which requires banks to build buffers in favourable conditions so that they can draw down on those buffers when conditions deteriorate.

Repullo et al. (2010) conducted a further study on the relationship between the Basel II capital requirements and the GDP growth rate for Spanish banks. Figure 3 below shows the smoothed capital requirements that would have evolved in Spain under Basel II, together with the Spanish GDP growth rate. The two time series are clearly strongly negatively correlated.

Figure 3

The negative correlation between Basel requirements and the business cycle for Spanish banks

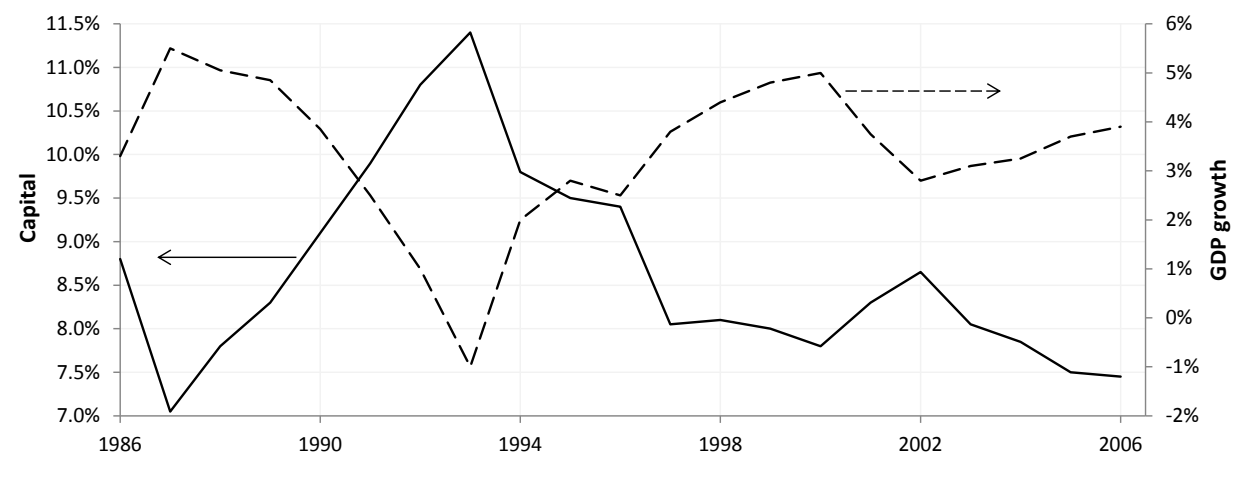

Source: Repullo et al. (2010) 
This means that banks are required to hold less capital during economic booms and more capital during economic downturns, which puts further strain on the banking sector during economic downturns. The reason for this is that the capital requirements are based on RWA. During economic booms, the probability of default for counterparties decreases, resulting in lower levels of RWA. This means lower capital requirements during economic booms. During economic downturns the opposite happens. Probability of default increases, resulting in higher levels of RWA and higher capital requirements.

To counter this negative correlation, Repullo et al. (2009) proposed smoothing the output of capital requirements through an adjustment to the point-in-time capital requirements by the multiplier $\mu_{t}$, defined by:

$$
\mu_{t}=\mu\left(g_{t}\right)=2 N\left(\frac{\alpha\left(g_{t}-\bar{g}\right)}{\sigma_{g}}\right)
$$

where $g_{t}$ is the rate of growth of the business cycle indicator, $\bar{g}$ is the long-term run average of the business cycle indicator, $\sigma_{g}$ is the longterm standard deviation of the business cycle indicator, $N(\cdot)$ is the standard normal cumulative distribution function and $\alpha$ is a positive parameter to be estimated. Minimum capital requirements under the Basel framework are calculated normally. The result is then multiplied by the multiplier $\mu_{t}$ to determine the new capital ratio at which the bank would function. The multiplier calculation is based on the gap between the current growth rate of the business cycle indicator and the long-term average of this indicator.

Capital requirements are increased in good times and reduced in bad times. Capital requirements are equal to 1 when $g_{t}=\bar{g}_{t}$, so there would be no adjustment at the midpoint of the cycle. Capital requirements are bounded between 1 and 2, so they do not increase boundlessly and never fall below minimum Basel requirements. The normalisation by $\sigma_{g}$ allows us to express capital surcharges or reductions per standard deviation of GDP growth. The multiplier is only activated when GDP growth exceeds its long-term average as shown in Figure 4. The multiplier increases as the gap widens and causes an increase in capital requirements. Capital requirements are steadily increased until the business cycle reaches its peak. When the downturn starts, capital requirements can be decreased steadily until the GDP growth has dropped to the longterm average.

Banks would have extra capital accumulated through the economic boom available to absorb losses as the economic cycle neared its trough and the multiplier would only be "activated" once credit growth was above the long-term average again, giving banks enough time to recover. The lower bound of 1 ensures that the multiplier would serve the same purpose as the CCB by building buffers in favourable economic conditions.

Figure 4

Multiplier function through different stages of the business cycle

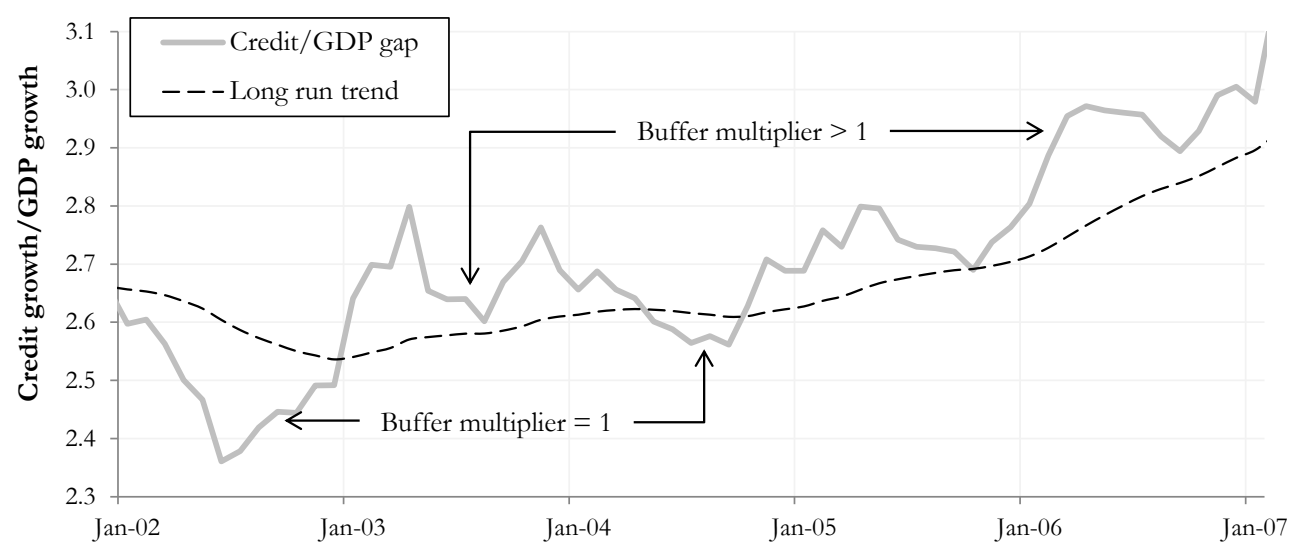


Repullo et al. (2010) state that dampening the excess cyclicality of minimum capital requirements with a multiplier of this kind is better than through-the-cycle approaches in terms of "simplicity, transparency, low cost of implementation, consistency with banks' risk pricing and risk management systems, and even consistency with the idea of a single aggregate risk factor that underlies the capital requirements of Basel". Using this kind of multiplier would mean that a fully rule-based instrument is used. This would require no supervisory intervention in decision-making processes, making it a pure Pillar 1 approach, which could be a major advantage for developing countries. Moreover, it would be completely transparent, so that at any point in the business cycle investors and analysts could observe both adjusted and unadjusted minimum capital requirements.

Importantly, minimum capital requirements would retain the full risk-sensitivity of Basel III in the cross-section, but allow the capital charge curve to shift with the state of the business cycle. During expansions, minimum requirements would be above those based on point-in-time PDs (probability of defaults), helping to slow the lending cycle and to build up a higher cushion of capital to be used to protect banks' solvency in bad times.

\subsection{Analysis of the Basel CCB proposals from a South African perspective}

South Africa has not yet experienced a full financial crisis, but rather periods of financial distress. The SARB identified three periods of financial distress in South Africa (SARB, 2011):

- 1985-1987: debt-standstill and flight of capital crisis;

- 1997-1999: impact of the South-East Asian crisis; and

- 2008-2010: impact of the global financial crisis.

The fact that South Africa has not experienced a full financial crisis makes identifying buildup and release indicators a difficult task. However, if indicators that provide early warning signals prior to periods of financial distress can be identified, these indicators may also function prior to periods of financial crisis. The SARB (2011) describes some preliminary work by the SARB in preparing for the $\mathrm{CCB}$.

\section{Credit-to-GDP gap}

The SARB's investigation into possible South African CCB measures explored a range of technical issues, such as which measures of credit should be used and what value of the smoothing parameter for the Hodrick-Prescott (HP) filter would be most suitable (SARB, 2011). The SARB's investigations used the growth of both nominal credit measures, i.e. narrow (private-sector) credit and the broader measure of credit. While the differences between the two are evident, it is also clear that there are similarities in the trends shown by both, with the narrow measure lagging behind developments in the broader one. However, the SARB concluded that the domestic CCB policy should be closely aligned with the details of the BCBS proposal and advised the use of the narrow definition of credit and a recommended smoothing parameter of 400000 for the HP filter. Using this definition and parameter, the credit-to-GDP gap for South Africa since 1965 is given in Figure 5 below (also see Van Vuuren, 2012).

This analysis shows that over the past three decades, the credit-to-GDP gap has been positive for numerous sustained periods.

The SARB concluded that:

The credit-to-GDP guide issued a strong warning signal for a buffer add-on for the 2006-2010 period, which could be interpreted as an indication of excessive credit growth on a system-wide basis in the domestic economy in the period leading up to the global financial crisis. The credit-to-GDP gap also issued warning signals in 1982-1986 and 1998-2000, which coincide with the two other periods of banking distress in South Africa. Despite the fact that the preliminary analysis of the private sector credit-to-GDP reference guide shows that it has promise of being a useful tool in developing a CCB policy in the domestic economy, there is ample reason to use this guide with caution and not to apply it either mechanically or uniformly. For instance, the credit-to- GDP ratio exceeded its long-term trend in the early 1990s, yet no local banking 
crisis took place during this time, and thus this particular signal is possibly an anomaly as it issued what could, for CCB purposes, be called a 'misleading' signal. Being a ratio, the credit-to-GDP gap will not only be affected by credit developments, but also by the GDP denominator behaviour. Therefore, interpretation of the gaps should be cognisant that the ratio and therefore the gap could be influenced by a cyclical slowdown or outright decline in gross domestic product (SARB, 2011).

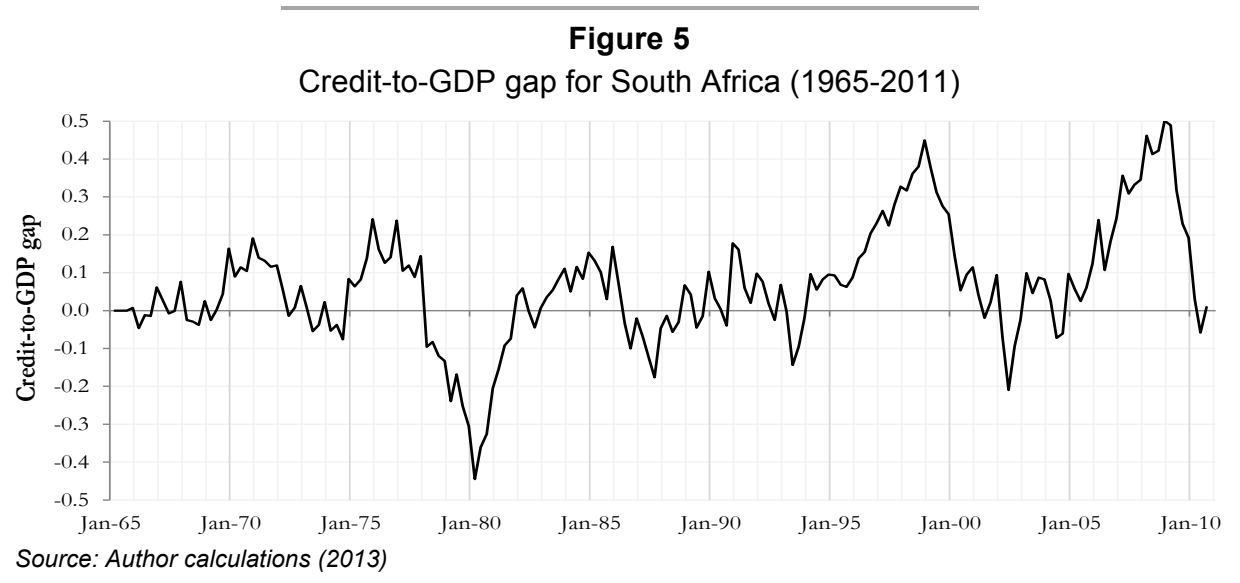

In avoiding incorrect conclusions, national authorities also need to distinguish between 'weak' and 'strong' signals from the credit-toGDP guide when making CCB decisions (BCBS, 2010c). SARB (2011) concludes that the credit-to-GDP gap seems to be a good indicator for South Africa, but there are some concerns. It has been shown to have been lagging in the 1997-1998 period of financial distress and it seems to be negatively correlated with the GDP.

The credit-to-GDP gap also provided some misleading signals during the early 1990s. A complete set of possible variables that could be used in conjunction with credit-to-GDP was thus explored. If a set of indicators is used it would be much easier to detect false warning signals and to ensure that no warning signals are missed. This is also congruent with the BCBS's suggestion that authorities should seek evidence as to whether conclusions drawn from the credit-to-GDP gap guide are consistent with those of other variables.

\section{Aggregate real credit growth}

An obvious alternative to the credit-to-GDP as the common reference point would be to use the deviation of credit growth from its longterm trend. Repullo and Salas (2011) argued that it would share the same rationale as the

credit-to-GDP gap in terms of being a leading indicator of a systemic banking crisis. Jorda, Schlarick and Taylor (2010) concluded that credit growth generates the best predictive signals of impending financial stability, based on data on financial crises in 14 countries over the past 140 years. The main advantage credit growth may have over the credit-to-GDP gap is that it would not have the additional lag introduced by using deviations of the credit-toGDP ratio with respect to its trend.

The financial cycle is often defined with reference to credit availability and credit growth is the most common measure of supply. Economic booms usually go hand-inhand with rapid credit expansion and a credit crunch is usually characterised by declines in overall credit. The deviation of credit growth from its long-term trend could be an informative variable. The SARB explored credit extension in their September 2011 study and produced results reflected in Figure 6 below.

The series exhibits four peaks, in 1973, 1981, 1988 and 2007. Credit extension picked up two of the three crises, but also gave two false signals. The main advantage of credit extension is that it is positively correlated with the business cycle. To obtain more accurate results, the main components of credit for the private sector were examined. 
Figure 6

Growth in broad and narrow credit in South Africa from 1966 to 2011

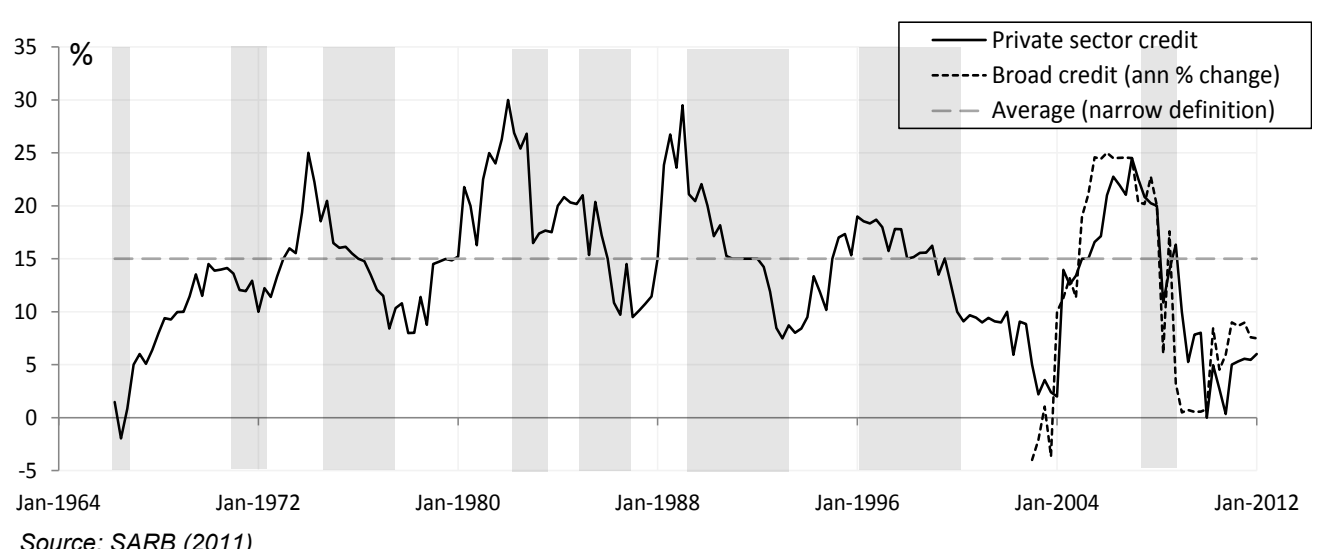

\subsection{Analysis of South African economic indicators}

In this section a number of domestic economic variables are analysed in order to determine which indicators are able to provide early warning signals of an imminent financial distress period. The complete list of economic variables considered is given in the Appendix; only the variables capable of producing early warning signals are discussed below. Since the $\mathrm{SARB}$ is required to announce its intention to build up the $\mathrm{CCB}$ at least 12 months in advance, the indicators will be analysed by their ability to produce clear warning signals at least 12 months prior to each of the three periods of financial distress. Early and extreme warning signal levels are identified by inspecting the graphs of the variables relative to their long-term trend.

\section{Advances to domestic private sector}

Advances to the domestic private sector are one of the main components of credit growth in South Africa. Data are available from 1992, so only the 1997-1999 and 2008-2010 periods of financial distress could be explored. The data were extracted from Bloomberg (2012). The deviations in advances to the domestic private sector from the long-term trend were used to analyse advances to the domestic private sector.

A deviation of 25 per cent from the longterm trend was identified as the early warning signal and 50 per cent as the extreme warning signal (see Figure 7).

\section{Figure 7}

Deviation of the advances to the domestic private sector from its long-term trend leading up to the 1997-1999 and 2008-2010 periods of financial distress

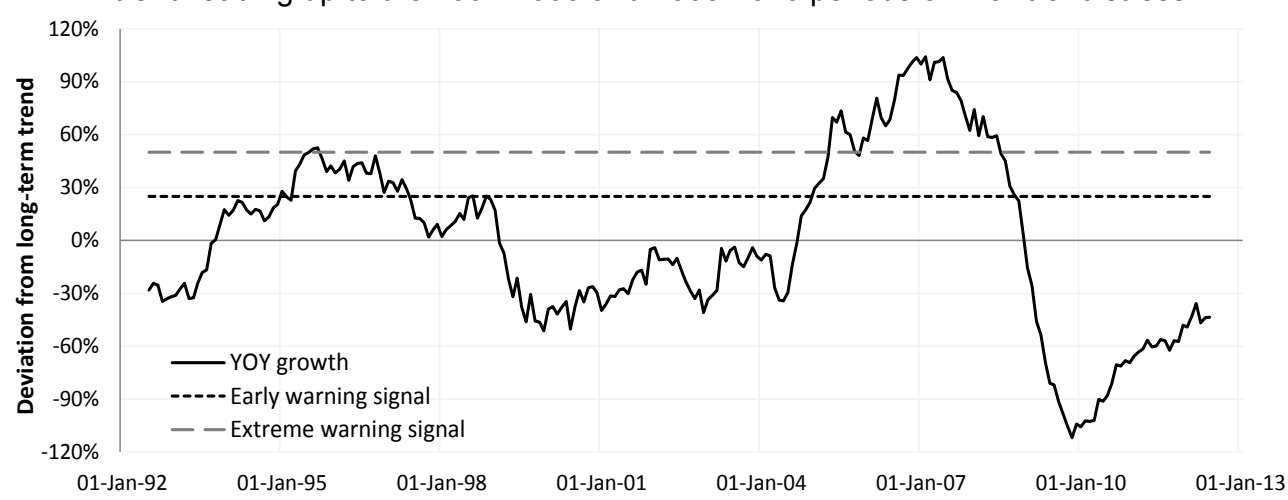


Regarding the impact of the East Asian crisis (1997-1999). Figure 7 shows that between January 1995 and 1997 early warning signals were observed, with one extreme signal just before the end of 1996. The warning signals for the global financial crisis (2008-2010) were of a far higher order, since extreme warning signals were observed from January 2005 to April 2008. Some early warning signals were present as far back as September 2004.

In summary, advances to the domestic private sector provide a promising leading indicator variable, giving strong signals prior to periods of financial distress.

\section{Number of new passenger vehicles sold}

The number of new passenger vehicles sold (rather than the value of new vehicles sold) was explored as another potential indicator of credit growth. The number of new vehicles sold is not influenced by increases in vehicle prices and provides a better indication of real credit expansion. Figures 8 to 10 were produced for each of the three periods of financial distress as identified by the SARB (SARB, 2011). This indicates whether there were clear warning signals 12 months prior to each of these periods of financial distress, as the CCB must be pre-announced by the SARB by up to 12 months.

The data were extracted from the SARB website. A deviation of 20 per cent from the 20-year long-term trend was taken as the early warning signal and a deviation of 40 per cent from the long-term trend as the extreme warning signal. Figure 8 shows the period leading up to the 1985-1987 period of financial distress. Spikes are observed in 1975 and 1978. These lasted for only short periods and cannot be seen to indicate a general build-up of systemic risk. Early warning signals are present in 1980: the extreme warning level was breached for the first time in 1981 and again in 1983.

Figure 8

Deviation of the number vehicles sold from its 20 -year long-term trend leading up to the 1985-1987 period of financial distress

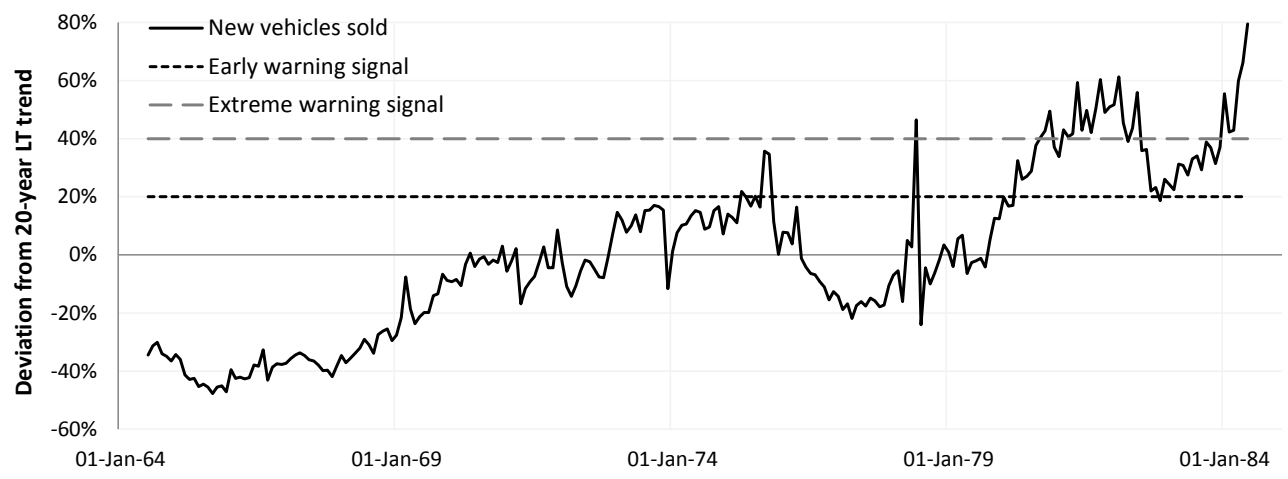

Figure 9 shows the period leading up to the 1997-1999 period of financial distress. Early warning signals were present in 1995, but these did not breach the extreme warning signal levels. This is closely correlated with the fact that the 1997-1999 period of financial distress was much less severe than the 19851987 and 2008-2010 periods because the East Asian economies had a far less significant effect on South Africa.
Figure 10 shows the period leading up to the 2008-2010 period of financial distress. The early warning signal level was breached in 2004 and the extreme warning levels early in 2005. The number of new passenger vehicles sold provides strong indicator signals, giving sufficient warning of all periods of financial distress experienced in South Africa. 
Figure 9

Deviation of the number of new vehicles sold from its 20 -year long-term trend leading up to the 1997-1999 period of financial distress

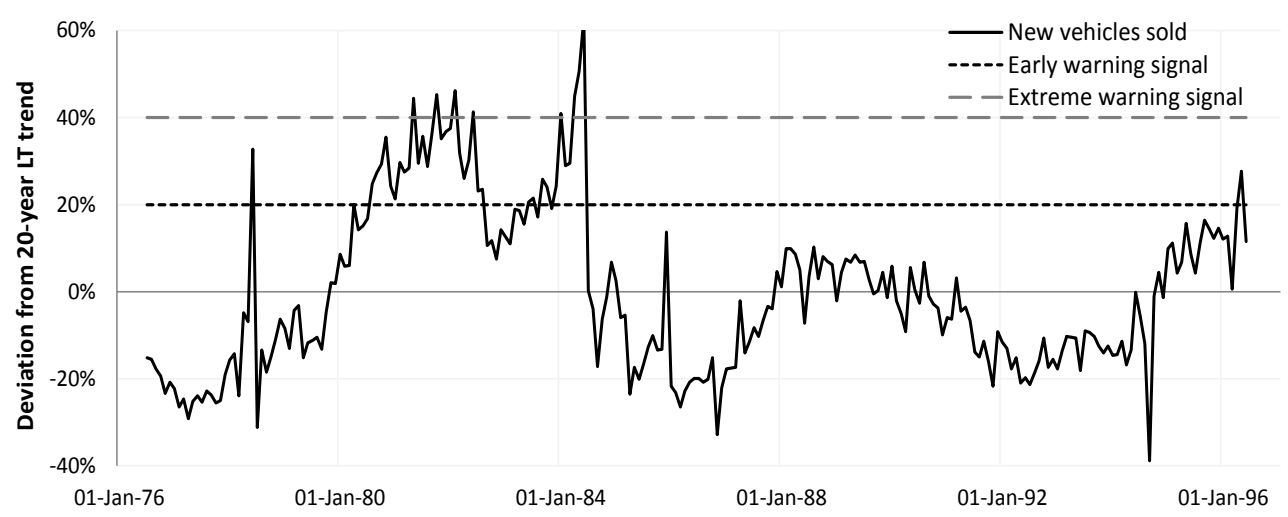

Figure 10

Deviation of the number of new vehicles sold from its 20 -year long-term trend leading up to the 2008-2010 period of financial distress

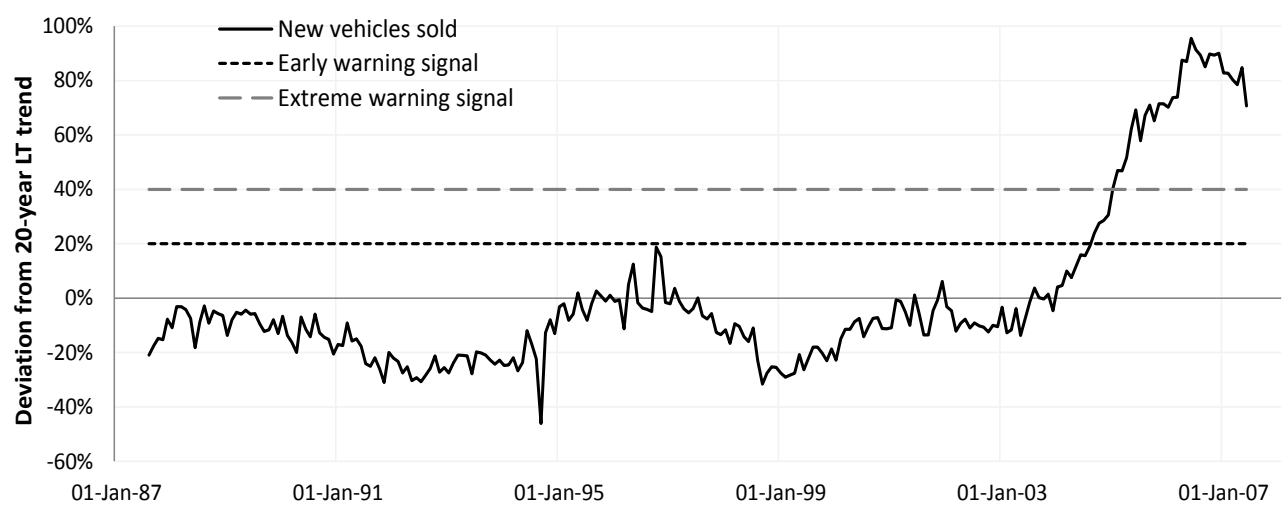

\section{ABSA House Price Index}

Property financing is another prominent component of credit growth in South Africa. The ABSA House Price Index for houses of all sizes was used; other South African house price indices provided limited data. The same methodology used to determine the number of new passenger vehicles sold was used for the ABSA House Price Index. The data were extracted from the McGregor BFA website. A deviation (from the long- run trend) of 50 per cent was used as the early warning signal and 100 per cent as an extreme warning signal.

Figure 11 reflects the period leading up to the 1985-1987 period of financial distress. In June 1980, early warning signals were present.
The extreme warning level was breached for the first time at the end of 1980, peaking around May 1981, four years ahead of the crisis.

Figure 12 shows the graph leading up to the 1997-1999 period of financial distress. It is clear that no warning signals were produced by the ABSA House Price Index for this period of financial distress. This corresponds with the fact that, because the effect of the East-Asian economies on South Africa was much less significant, the 1997-1999 period of financial distress was far less severe than the 1985-1987 and 2008-2010 periods, but raises concerns that this index may fail to detect some signals for financial crises. 
Figure 11

Deviation of the ABSA House Price Index from its 20-year long-term trend leading up to the 1985-1987 period of financial distress

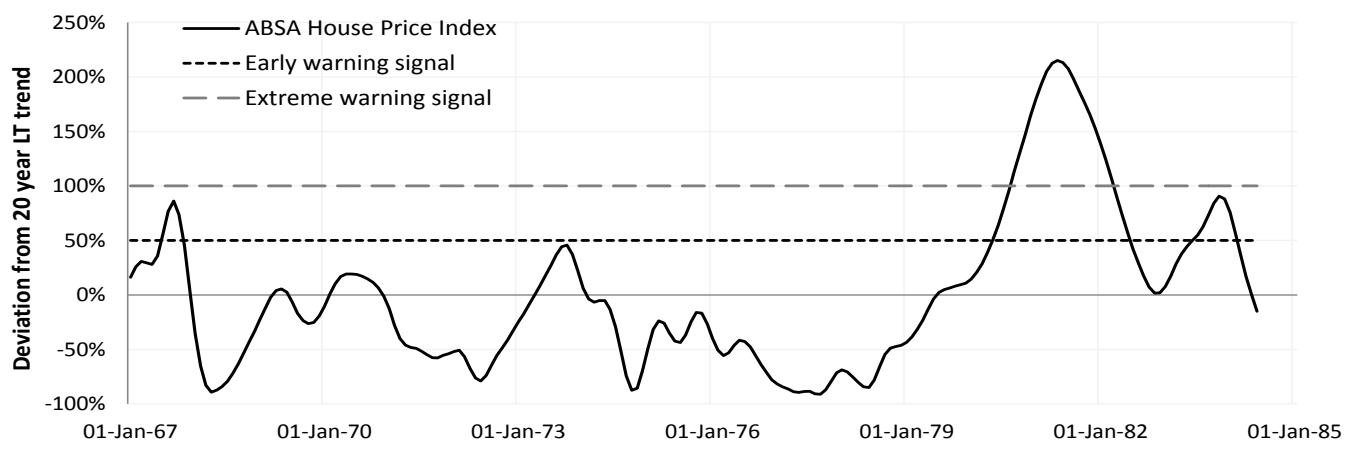

Figure 12

Deviation of the ABSA House Price Index from its 20-year long-term trend leading up to the 1997-1999 period of financial distress

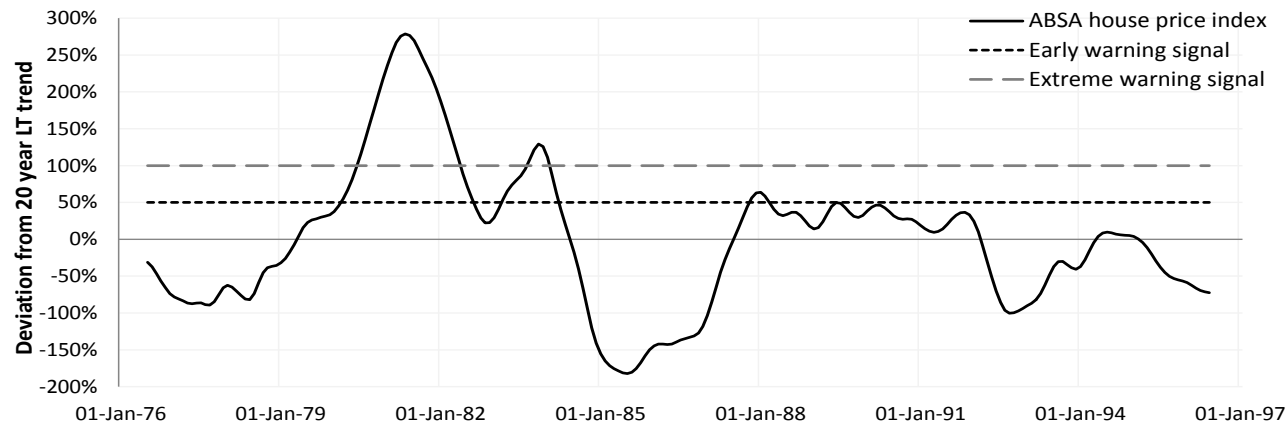

Figure 13 reflects the period leading up to the 2008-2010 period of financial distress. At the end of 2000 there were some early warning signals. This peak only lasted for a short time and would not be regarded as a general build-

up of systemic risk. The next early warning signal came in the first quarter of 2003. The extreme warning level was breached at the beginning of 2004 for the first time, peaking in October 2004, four years ahead of the crisis.

Figure 13

Deviation of the ABSA House Price Index from its 20-year long-term trend leading up to the 2008-2010 period of financial distress

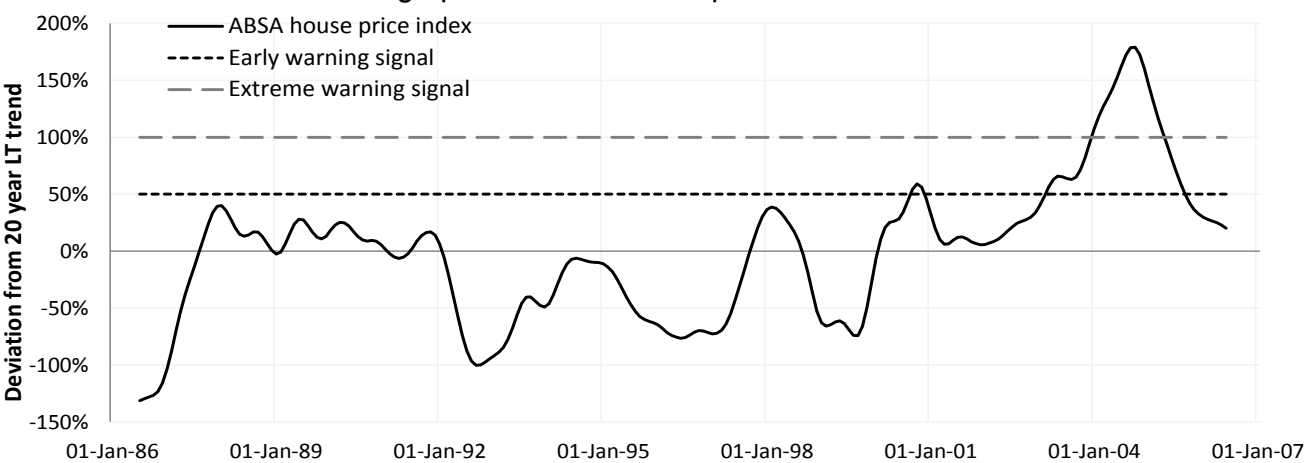


The ABSA House Price Index also provides a good indicator, as can be seen from the fact that it gave sufficient warning signals for the two major periods of financial distress. The fact that it gave no signal at all for the 19971999 period may raise some concerns, but the SARB should consider including this indicator in their set of leading indicators

\section{Building plans passed}

To determine whether increases in building costs are the only driver for increases in house prices, the number of building plans passed were analysed to supplement the ABSA House Price Index. The number of building plans passed is a real indicator of the state of the real estate market and, when coupled with the ABSA House Price Index, should provide a clear indication of credit extension in the real estate market.

The same methodology used to produce the previous graphs was used to reflect the number of building plans passed. Data are only available from 1985, so it was only possible to explore the 1997-1999 and the 2008-2010 periods of financial distress. The data were extracted from Stats SA. The deviation of the number of building plans passed from the 11- year long-term trend for the 1997-1999 period (due to data restrictions) and the deviation from the 20-year long-term trend for the 20082010 period were used. A deviation of 20 per cent from the long-term trend was identified as the early warning signal and 40 per cent as the extreme warning signal. Figure 14 is a graphical representation of the period leading up to the 1997-1999 period of financial distress. A build-up is present from the beginning of 1994 . The early warning signal buffer was breached at the end of January 1995, and the extreme warning signal was breached in March, but only for a short time. The early warning signal was breached three times at the beginning of 1996. This corresponds with the fact that the 1997-1999 period of financial distress was much less severe than the 1985-1987 and 2008-2010 periods of financial distress owing to the fact that the East-Asian economies had a less significant effect on South Africa. Data on building plans passed provide more accurate signals for this period than the ABSA House Price Index and would be a good supplement to the ABSA House Price Index.

Figure 14

Deviation of the number of building plans passed from its 11-year long-term trend leading up to the 1997-1999 period of financial distress

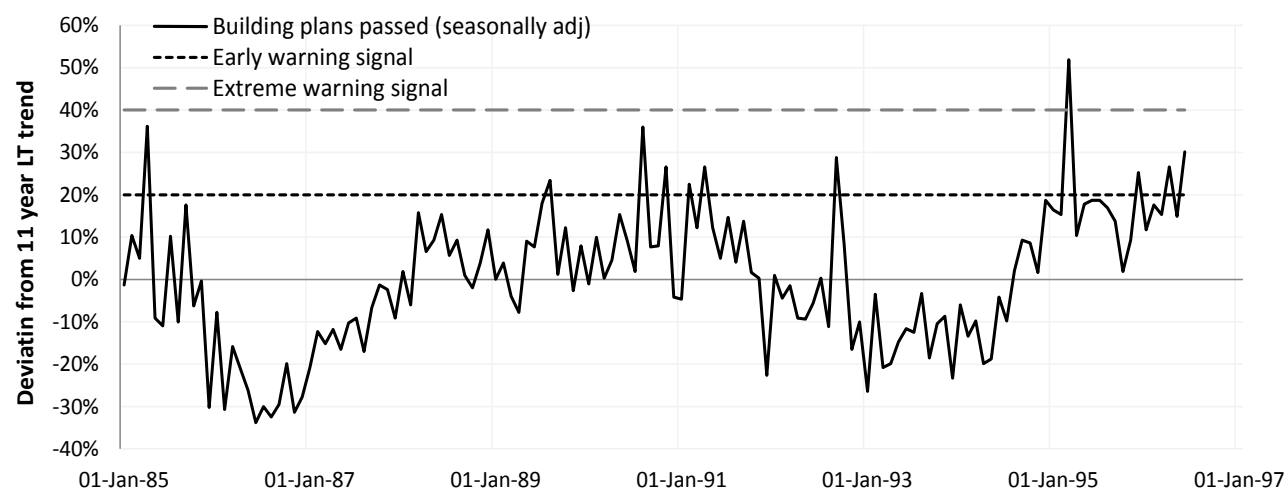

Figure 15 is a graphical representation of the number of building plans passed in the period leading up to the 2008-2010 period of financial distress. At the end of 2000 there were some early warning signals. This peak only lasted for a short time and would not be regarded as indicating a general build-up of systemic risk.
The next early warning signal came in the second semester of 2004. The extreme warning level was breached for the first time at the end of 2004, after which it dropped and was then breached again from around June 2005 ahead of the crisis. 
Figure 15

Deviation of the number of building plans passed from its 20-year long-term trend leading up to the 2008-2010 period of financial distress

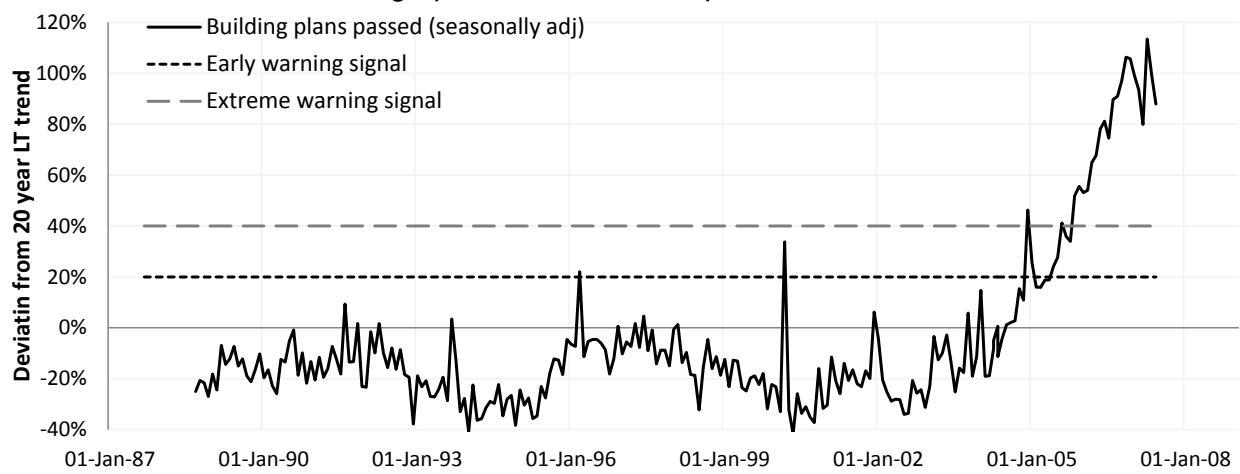

The number of building plans passed seems to be another promising leading indicator of a build-up of systemic risk. When coupled with the ABSA House Price Index it would definitely give clear signals if there is a buildup of risk in the mortgage market.

Many indicator variables were analysed for this study but most delivered no positive results. However, the set of possible leading indicators for the build-up phase discussed above delivered some promising results and would undoubtedly deliver good results if used to evaluate the build-up of system-wide risk. Since South Africa is still a developing country with a changing economic environment, the main focus must be on how the leading indicators performed during the latest period of financial distress, namely 2008-2010. All leading indicators discussed above gave accurate and timely warning signals in the period leading up to the 2008-2010 global financial crisis. The only remaining concern is the fact that the leading indicators should preferably be positively correlated with the business cycle because one would like to build up the CCB when economic conditions are favourable and when the GDP is growing.

\subsection{Build-up indicators and the business cycle}

To ensure that capital buffers are built up in good economic times it is very important that the indicator variables should be positively correlated with the business cycle. The standard business cycle indicator that was used for this study is the rate of growth of the GDP in South Africa. The data were extracted from the SARB website.

Figure 16 shows the correlation between the set of leading indicators discussed above and the GDP growth rate in South Africa. All variables are positively correlated with the GDP except one, the credit-to-GDP gap, which the BCBS prescribed as the "common reference point". The rest of the variables produced satisfying results and could be used by the SARB. The negative correlation between the credit-to-GDP gap and the GDP growth rate raises some concern and is in agreement with the findings of Beck and Demirguc-Kunt (2009). The negative correlation means that the credit-to-GDP gap would indicate the need to reduce capital requirements when GDP growth is high, and to increase capital requirements when GDP growth is low. The credit-to-GDP gap is therefore not a leading indicator in the sense that the signals it provides suggest that capital should be built up during the crisis and not before the crisis, when economic conditions are favourable.

Indicators that should be used to time the release of the buffer will be discussed next.

\subsection{Release indicators}

The timing of the release of the CCB is critical to the success of the instrument. The buffer must be released when it can still play a preventive role, otherwise the objectives of the instrument will not be achieved. The buffer 
must present banks with a cushion that will enable them to absorb losses during the downturn. Risky credit practices are likely to underlie excessive asset growth in the books of the banking sector. According to Shin (2010), rapid loan growth is often achieved "only at the cost of lowering lending standards". Accordingly, it is to be expected that the underlying vulnerability of the loan book will be exposed by a downturn.

Figure 16

Correlation of the leading indicator variables with South African GDP growth

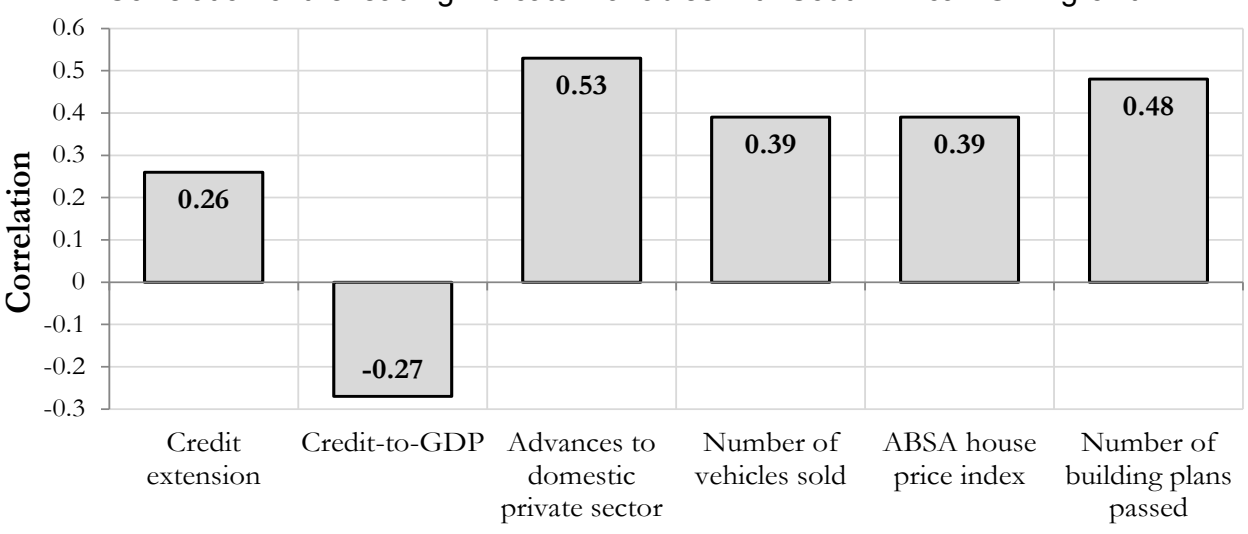

The SARB analysed this in their September 2011 report (SARB, 2011). The South African banking sector's gross loans and advances increased significantly between 2003 and 2006. Throughout this lending boom, nonperforming loans decreased, but as the effects of the global financial crisis set in after 2007, loan growth decreased rapidly. Recessionary conditions exposed weaknesses in some loan books, resulting in non-performing loans increasing to approximately 6.5 per cent of gross loans and advances.

The phenomenon of declining loan growth and an increase in the number of nonperforming loans could become another development to monitor when assessing the build-up of systemic risks in the banking system for CCB policy purposes (SARB, 2011). Authorities may therefore also wish to monitor developments in the levels of provision to confirm deterioration of the loan books in the banking sector.

Figure 17

Loan growth and non-performing loans for the South African banking sector

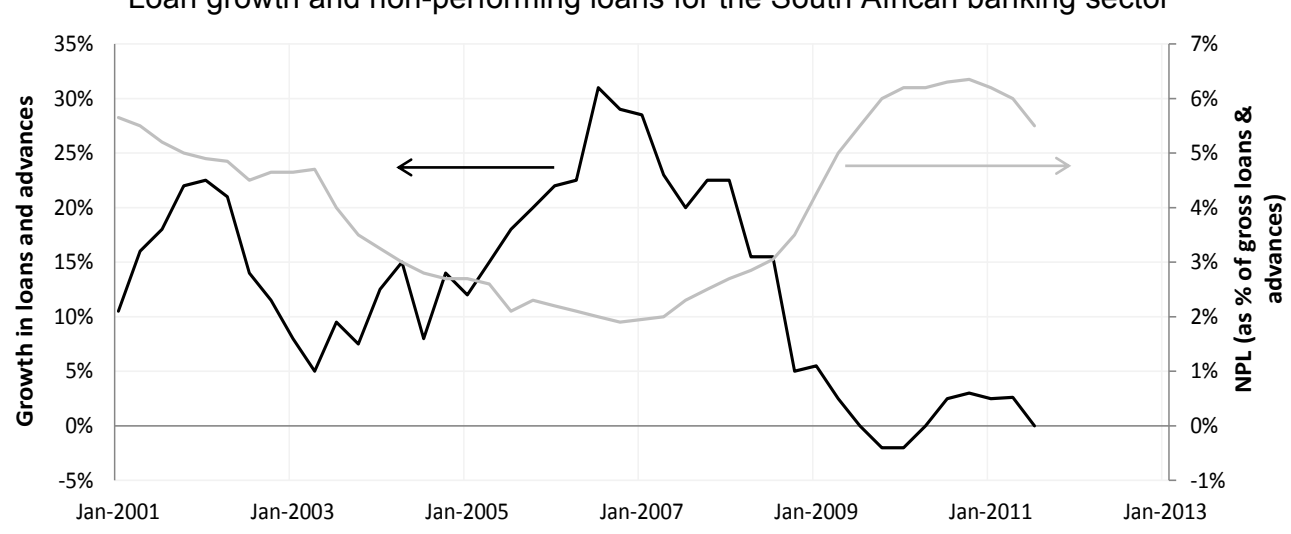

Source: SARB (2011) 
'Non-performing loans' are defined as exposures overdue for 90 days. For the period prior to January 2008, the "90 days overdue" data included the substandard, doubtful and loss categories (based on the regulations aligned to Basel I). From January 2008 onwards (i) for banks that utilised the standardised approach for credit risk, the data for the substandard, doubtful and loss categories were included; and (ii) for banks that utilised the internal ratings-based approach for credit risk, the exposures classified as defaults were included (SARB, 2011).

Many banking performance indicators that could assist with the release phase were analysed, but loan growth and non-performing loan growth figures perform the best for the release phase of the CCB. These two indicators provide the most accurate information as to when banks could benefit from the release of the buffer. As can be seen from Figure 17, loan growth starts to decrease when banks consider that a possible recession may be on the horizon. This could serve as a signal to the $\mathrm{SARB}$, and as soon as non-performing loans start increasing, coupled with their own assessment of current economic conditions and forecasts, the buffer could be released to help banks to absorb their losses. This will ensure that the release of the buffer is timely, and can play a preventive role in the banking sector.
It is evident that the correct timing for the build-up and release phases of the $\mathrm{CCB}$ is crucial to the success of the instrument. The set of indicators identified to assist with this process have performed well historically and could help to identify a build-up of systemic risk in the banking sector. The credit-to-GDP gap as "common reference point" raised some concern regarding the negative correlation with the GDP and must therefore not be used mechanically or as the only indicator of the build-up of systemic risk. The performance of the complete set of indicators identified in this section should rather be used to identify a build-up of systemic risk. Using the complete set would ensure that no signals are missed and that misleading signals can be identified. This would ensure accurate and timely build-up phases for the buffer. Analysing banking loan growth and non-performing loan growth, coupled with supervisory discretion, seems to be the best strategy for the release of the buffer.

\subsection{Summary}

Table 6 below contains a summary of the analysis of leading indicators able to produce early warning signals for the build-up of systemic risk by using the classification scheme given in Table 5 below.

Table 5

Classification scheme for the ability of indicators to produce early warning signals

\begin{tabular}{|l|l|}
\hline \multicolumn{1}{|c|}{ Classification } & \multicolumn{1}{c|}{ Description } \\
\hline None & No ability to produce early warning signals \\
\hline Weak & Some ability close to 12 months in advance, but generally late \\
\hline Medium & Good ability in advance of 12 months but generally not clear signals \\
\hline Strong & Definite ability well in advance of 12 months \\
\hline
\end{tabular}

Table 6

Indicators classified in terms of their ability to provide early warning signals

\begin{tabular}{|l|c|c|c|c|}
\hline \multicolumn{1}{|c|}{ Indicator } & $\begin{array}{c}\text { Distress period } \\
(1985-1987)\end{array}$ & $\begin{array}{c}\text { Distress period } \\
(1997-1999)\end{array}$ & $\begin{array}{c}\text { Distress period } \\
(2008-2010)\end{array}$ & $\begin{array}{c}\text { False signals } \\
\text { present }\end{array}$ \\
\hline Credit-to-GDP gap (analysed by SARB) & Weak & Weak & Medium & Yes \\
\hline $\begin{array}{l}\text { Growth in private sector credit (analysed by } \\
\text { SARB) }\end{array}$ & Weak & None & Medium & Yes \\
\hline Advances to the domestic sector & No data & Medium & Strong & No \\
\hline Number of new passenger vehicles sold & Strong & Medium & Strong & No \\
\hline ABSA House Price Index & Strong & None & Strong & No \\
\hline Building plans passed & No data & Medium & Strong & No \\
\hline
\end{tabular}


5

\section{Conclusion and recommendations for further research}

The SARB has indicated that South Africa will not opt for early implementation of the CCB and will focus on implementing the instrument from 1 January 2016, as stipulated by the BCBS implementation time frame. Before this paper, the only work done on the CCB specific to South Africa was published by the SARB in their September 2011 Financial Stability report. In this report the credit-to-GDP gap for South Africa was assessed and some options on leading indicators that would issue accurate warning signals when there was a build-up of systemic risk due to excess aggregate credit growth were explored. These and other indicator variables were evaluated and a complete set of leading indicators that could be used by the SARB to assess whether there is a build-up of systemic risk was proposed. These indicators included advances to the private domestic sector, new passenger cars sold, house price indices, credit extension, and the "common reference" point proposed by the BCBS: the credit-to-GDP gap. All these indicators (except the credit-to-GDP gap) proved to be positively correlated with GDP growth. This would ensure that the buffer accumulates in good times and would therefore reduce the cyclicality of minimum capital requirements.

Lagging and leading indicator times for the indicator variables could be considered by the SARB (these are currently (2014) unaddressed). Frequent revision to the relevant metric inputs, such as the GDP, should also be taken into account, before these measures gain widespread acceptance in the financial milieu.

The credit-to-GDP gap is negatively correlated with GDP growth. This reduces capital requirements in favourable conditions and increases them in unfavourable ones, putting extra pressure on banks. Closer inspection indicated that accurate build-up signals were still present, but that their performance was much weaker for the release phase. The complete set of proposed indicators should only be used for the build-up phase, and loan growth and growth in non-performing loans, coupled with regulatory judgement of economic conditions, should be used to release the buffer in good time. South African banks are well capitalised and even if a maximum countercyclical capital buffer of $2.50 \% \times R W A$ were deployed, South African banks would still function above these required capital ratios.

Further work is needed to explore the findings of Repullo in the South African context. This, together with the indicators identified, should be combined in a joint framework to provide early warning signals for periods of financial distress. Such a framework could help the SARB to decide when to build up the CCB in good times and release the CCB towards the end of bad times.

The SARB could extend its focus from bank stability to South African household sector leverage, as proposed by Walters (2011) and Van Vuuren (2012). This leverage is high (2014) and would pose a fundamental risk to the South African economy if interest rates were suddenly raised to rein in inflation. This has now transpired: the US has begun reducing its quantitative easing programme, revenues have flowed out of emerging economies back to the US and the affected countries have swiftly raised interest rates (Tora, 2014). It remains uncertain how much further interest rates will rise, but if the substantial devaluation of the South African rand continues, this seems likely (Bosley \& Vollgraaff, 2014).

\section{Acknowledgements}

The last author carried out this research at Deloitte and Touche as part of his six-month Business Mathematics and Informatics (BMI) industry-directed research project in partial fulfilment of the degree of Master of Science in BMI. During this period some discussions were held with representatives of the SARB that significantly improved the relevance of the results obtained. The authors acknowledge the grants received from the National Research Foundation, the Department of Science and Technology and the Department of Trade and Industry. All opinions, findings and conclusions or recommendations expressed in this material are those of the authors and therefore the NRF does not accept any liability in regard thereto. 


\section{References}

ATHANASOGLOU, P.P., DANIILIDIS, I. \& DELIS, M.D. 2014. Bank procyclicality and output: Issues and policies. Journal of Economics and Business, 72:58-83.

BCBS. 2009. Strengthening the resilience of the banking sector. Consultative document. Bank for International Settlements.

BCBS. 2010a. Guidance for national authorities operating the countercyclical capital buffer. Bank for International Settlements.

BCBS. 2010b. Basel III: A global regulatory framework for more resilient banks and banking systems. Bank for International Settlements.

BCBS. 2010c. Countercyclical capital buffer proposal. Consultative document. Bank for International Settlements.

BCBS. 2011 Basel III: A global regulatory framework for more resilient banks and banking systems. Bank for International Settlements.

BECK, T. \& DEMIRGUC-KUNT, A. 2009. Financial institutions and markets across countries and over time: Data and analysis. World Bank Policy Research Working Paper No. 4943.

BLOOMBERG. 2012. Risk weighted assets. Available at: http://www.bloomberg.com [accessed 2012-08$01]$.

BOSLEY, C. \& VOLLGRAAFF, R. 2014. Gordhan says weaker South African rand should boost exports, Bloomberg News, 25 January 2014.

DREHMANN, M., CLÁUDIO, B., GAMBACORTA, L., JIMENEZ, G. \& TRUCHARTE, C. 2010. Countercyclical capital buffers: Exploring options. Available at: http://www.bis.org/publ/work317.pdf [accessed 2011-02-12].

GORDY, M. 2009. First do no harm - a Hippocratic approach to procyclicality in Basel II. Netherlands Bank.

HANSON, S. KASHYAP, A \& STEIN, J. 2011. A macroprudential approach to financial regulation. Journal of Economic Perspectives, 25(1):3-28.

JORDA, O., SCHLARICK, M. \& TAYLOR, A. 2010. Financial crises, credit booms and external imbalances: 140 years of lessons. NBER Working Paper No. 16567.

KASHYAP, A. \& STEIN, J. 2004. Cyclical implications of Basel II capital standards. Federal Reserve Bank of Chicago:18-31.

REPULLO, R. \& SALAS, J. 2011. The countercyclical capital buffer of Basel III: A critical assessment. CEPR Discussion Paper No. DP8304. Available at SSRN: http://ssrn.com/abstract=1794894 [accessed 201208-02].

REPULLO, R. SAURINA, J. \& TRUCHARTE, C. 2010. Mitigating the procyclicality of Basel II. Economic Policy.

REPULLO, R. \& SAUREZ, J. 2009. The procyclical effects of Basel II. CEPR Discussion Paper No. 6862. SARB. 2011. Financial stability review September 2011. South African Reserve Bank, Pretoria, South Africa.

SHIN, H. 2010. Macroprudential policies beyond Basel III. International Centre for Financial Regulation, London.

SHLEIFER, A. \& VISHNY, R. 2010. Unstable banking. Journal of Financial Economics:306-318. TORA, B. 2014. Emerging markets first to suffer as QE is wound down. Financial Times, 6 February 2014. VAN VUUREN, G. 2012. Basel III countercyclical capital rules: Implications for South Africa, SAJEMS, 15(3):309-324.

WALTERS, S. 2011. South African Reserve Bank, Quarterly Bulletin, December 2011. Available at: https://www.resbank.co.za/Lists/News\%20and\%20Publications/Attachments/4899/01Full\%20Quarterly\%20 Bulletin.pdf [accessed 2012-09-22]. 


\section{Appendix: Indicators analysed}

In the table below all the indicators are listed that was analysed as possible leading indicators, but proved to be ineffective in predicting the build-up of systemic risk

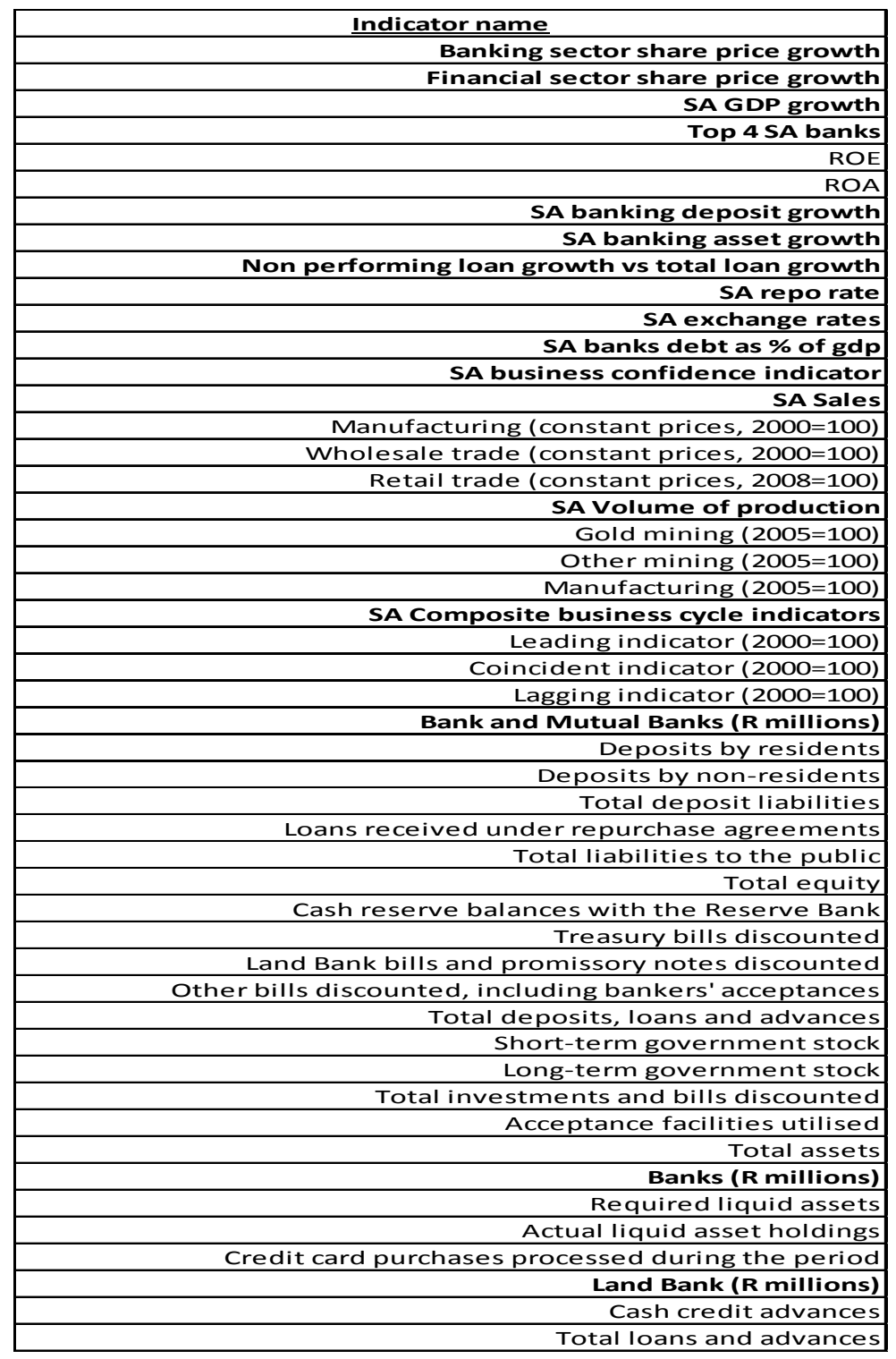

